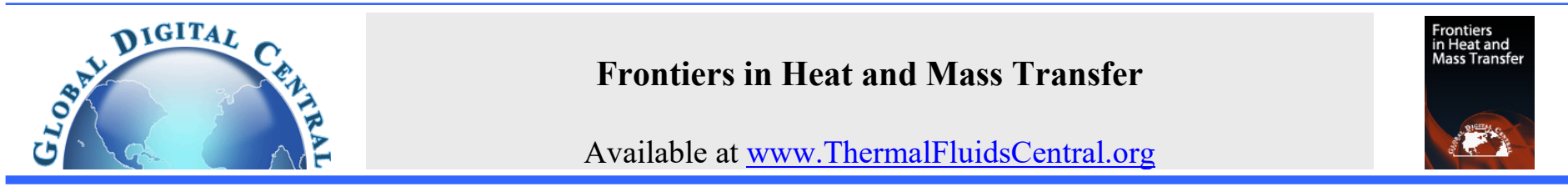

\title{
BATTERY COOLING OPTIONS IN ELECTRIC VEHICLES WITH HEAT PIPES
}

\author{
Randeep Singh $^{\mathrm{a},{ }^{,}, \dagger}$ Gero Lapp ${ }^{\mathrm{a}}$, Jason Velardo ${ }^{\mathrm{b}}$, Phan Thanh Long ${ }^{\mathrm{a}}$, Masataka Mochizuki ${ }^{\mathrm{c}}$, Aliakbar Akbarzadeh ${ }^{\mathrm{d}}$, Abhijit $^{\circ}$ \\ Date $^{\mathrm{d}}$, Karsten Mausolf ${ }^{\mathrm{e}}$, Kristin Busse ${ }^{\mathrm{e}}$ \\ ${ }^{a}$ Fujikura Automotive Europe GmbH, Manchinger Strasse 114, D-85053 Ingolstadt, Germany \\ ${ }^{b}$ Fujikura Ltd., 1-5-1, Kiba, Koto-Ku, Tokyo 135-8512, Japan \\ ${ }^{c}$ The Heat Pipes, Shiohama 1-4-33-1022, Koto-ku, Tokyo 135-0043, Japan \\ ${ }^{d}$ School of Engineering, RMIT University, Melbourne 3000, Australia \\ ${ }^{e}$ Volkswagen AG, Brieffach 013/37610, D-38112 Braunschweig, Germany
}

\begin{abstract}
In this paper, different options, based on heat pipes, for thermal management of electric vehicle (EV) battery system, at cell, module and pack level, for 40 to $400 \mathrm{~W}$ output heat, has been explored, analysed and compared. Cooling architecture based on embedded heat pipe (EHP) with single phase pumped cold plate (CP), as most adaptable design for low to medium range EVs, while EHP with loop heat pipe (LHP) as high performance design for high-end carlines, has been classified as potential cooling systems. Experimentally, it was shown that EHPs will provide best performance for heat acquisition at cell/module level, while LHPs for heat transport at pack/system level. In summary, two phase thermal management system, for lithium-ion battery, will help to improve overall system cooling performance, reliability, safety and reduce design complexity.
\end{abstract}

Keywords: Automotive thermal control, Battery Electric Vehicle, Lithium-ion battery, capillary heat pipes, Loop heat pipe, cold plates

\section{INTRODUCTION}

Future trends in automotive is towards autonomous drive and electrification. By 2025, 1 in 6 cars on road will be full hybrid or electric to control emissions and move towards high performance, high functionalities vehicles. Average vehicle emissions (gm of CO2 per km) around the world are targeted to reduce from $150 \mathrm{~g} / \mathrm{km}$ to below $95 \mathrm{~g} / \mathrm{km}$ by 2025 (Tilley, 20218). With the development in cell chemistry and battery technologies, range per charge for EVs is expected to match ( $700 \mathrm{~km}$ ) current tank mileage for conventional gasoline vehicles by 2030 . Electric vehicles have fully electrical propulsion system that includes battery system and electric motor as the main components for automotive traction. These power systems are complemented by auxiliary components for power transmission, power conversion (power electronics i.e. invertor, DC/DC convertor) and battery charging (onboard/induction charger, charging port) as shown in Fig. 1.

Most components of electric drive train requires thermal management for performance and longevity. Electrical (e.g. e-motors) and electronic systems (e.g. IGBTs) can sustain higher operating temperatures $\left(\sim 70\right.$ to $\left.85^{\circ} \mathrm{C}\right)$ than electrochemical systems like battery cells $\left(\sim 40{ }^{\circ} \mathrm{C}\right)$ (Jeckel, 2018). Lithium-Ion (Li-ion) cells, in either cylindrical, prismatic or pouch form, are invariably used for automotive batteries owing to their high energy density and better chargingdischarging efficiency.

For good calendar life and performance of Li-ion battery, temperatures should be maintained within narrow temperature range 25 to $40^{\circ} \mathrm{C}$. For lower temperatures $\left(<25^{\circ} \mathrm{C}\right)$, battery need heating, and, for higher temperatures $\left(>40^{\circ} \mathrm{C}\right)$, there is a need for cooling the cells, to maintain good cyclic efficiency, state of charge (SOC) and overall lifetime.

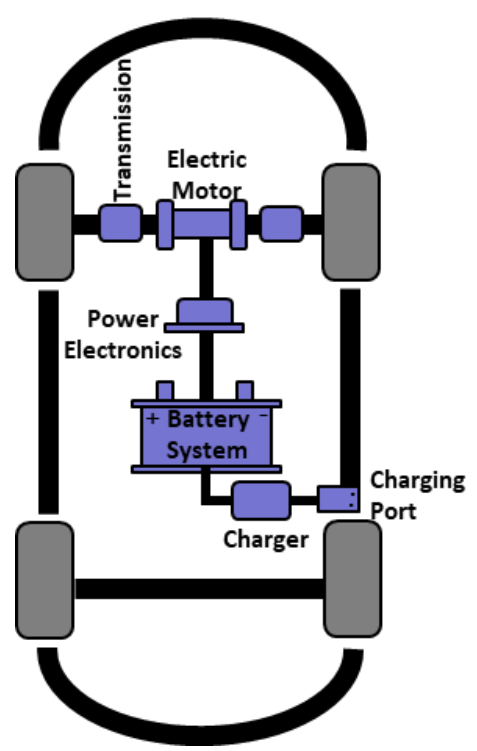

Fig. 1 Electrified propulsion system in electric vehicle showing battery system and motor along with control electronics

Cell resistance increases with drop in temperature while cell chemistry degrades with increase in temperature, therefore an optimum balance of performance and lifetime is needed, which is achievable at

\footnotetext{
* Currently in Thermal Engineering at Fujikura Automotive Europe, Ingolstadt, Germany

† Corresponding author. Email: randeep.singh@jp.fujikura.com
} 
narrow temperature band as specified above. It should be noted that optimum temperature range depends on cell chemistry, for example, Liions cells operates favourable around $40{ }^{\circ} \mathrm{C}$ whereas solid-state cells have best performance around $80^{\circ} \mathrm{C}$. For a battery electric vehicle (BEV), the range can reduce by $18 \%$ when driving on hot summer day $\left(+35^{\circ} \mathrm{C}\right.$, $40 \% \mathrm{RH})$ and by $36 \%$ when driving on cold winter day $\left(\sim-10{ }^{\circ} \mathrm{C}, 90 \%\right.$ $\mathrm{RH}$ ), due to cabin and battery thermal management (Ferraris et al, 2018). Based on aforesaid facts, it can be safely asserted that thermal management of automotive batteries is very critical for vehicle range (economy), performance and lifetime cost.

Overall battery system consists of battery modules and associated control electronics (cell/battery management system, battery junction box). Fig. 2 presents waste heat output by different components of propulsion system. High heat load from battery module is attributed to fast charge/discharge requirements in electric vehicle. Please note, heat losses provided in Fig. 2 should be taken as indicative values only. Depending on technologies used for particular component, heat losses can vary considerably. Heat output $\sim 200 \mathrm{~W}$ for one module implies 25 $\mathrm{W}$ per cell for 8 cells module. Device characteristic length, in Fig. 2, represents length of battery module, which also outlines possible length of heat pipe needed for thermal management of module. It should be noted that Fig. 2 provide heat load from single module. For Plug in hybrid electric vehicle (PHEV), approx. 8 such modules are installed, whereas for battery electric vehicle (BEV) as much as 20 such module could be present. In this case, cooling system is required to handle heat load in $\mathrm{kW}$ range ( $\sim 1.6 \mathrm{~kW}$ for PHEV and $4 \mathrm{~kW}$ for BEV). Depending on space and thermal specifications, air cooling can be used for $<0.5 \mathrm{~kW}$ system whereas liquid cooling is inevitable for $>0.5 \mathrm{~kW}$ battery systems.

Heat is generated inside battery cells due to electrochemical reaction and joule heating, which need to be removed and dissipated externally to keep cells and overall module temperature within permissible limits. Here, heat is not necessarily generated on continual basis, for example, there would be high heat losses during fast charging (at charging station in stationary state) and fast discharging (i.e. fast accelerations during dynamic state). This means cooling requirement of battery system changes continuously which requires active sensing and feedback control to avoid overcooling or overheating of battery cells.

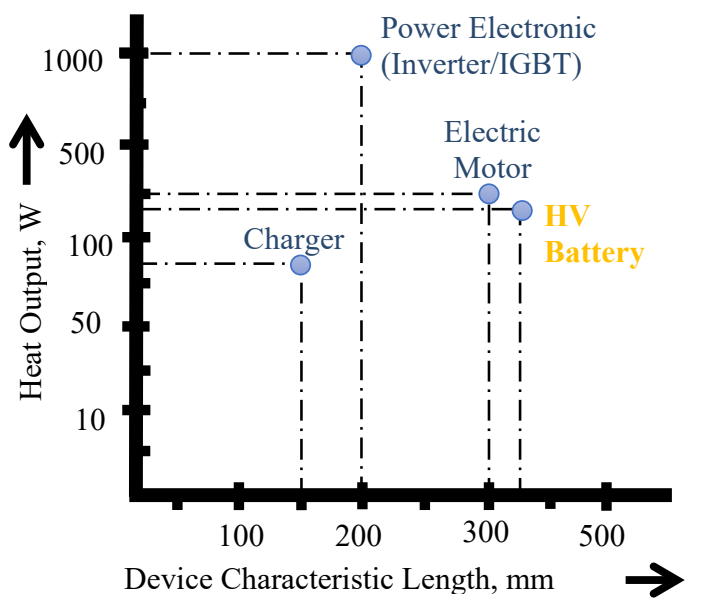

Fig. 2 Heat load from different components of propulsion system in electric vehicle

At present, more than $70 \%$ of automotive battery systems are cooled by forced air, and 18\% are cooled by coolant (Tilley, 20218), which is expected to increase to 3 times by 2023 timeline, due to increase in energy density and thus heat losses from cells. Temperature uniformity and safety against overheating are two main requirements for battery cells to maintain their optimum performance and lifespan. With single phase fluid (air or liquid), only marginal temperature uniformity could be achieved due to smaller specific heat capacity of fluids and limitation on flow rate (pumping power). Additionally, liquid coolant poses leakage hazard (safety issue) in high voltage area. Two-phase system based on heat pipes can help to address these issues effectively. Heat pipes have been investigated for range of electronics and electrical system cooling in automotive (Singh et al, 2015, 2016; Orr et al, 2016; Mochizuki et al, 2016). In the present paper, different design configurations for battery module cooling based on two phase principle using heat pipes have been proposed and evaluated. The paper will specifically address overall cooling architecture for EV battery cooling, with particular attention on performance, integration and safety aspects. Please note, for simplicity, design proposal and discussion is limited to battery module level only. System approach outlined in the paper can be easily extrapolated and used for complete pack analysis and design purposes.

\section{BATTERY MODULE DESIGN}

Fig. 3 present the battery module with key dimensions. For this investigation, battery modules with 8 to $12 \mathrm{Li}$-ion prismatic cells with individual cell dimensions of 148 (L) x 91 (W) x 26.5 (T), making up total stack length of $\sim 280$ to $350 \mathrm{~mm}$ is considered. Each cell has maximum $4.2 \mathrm{~V}$ with 25 Ah capacity.

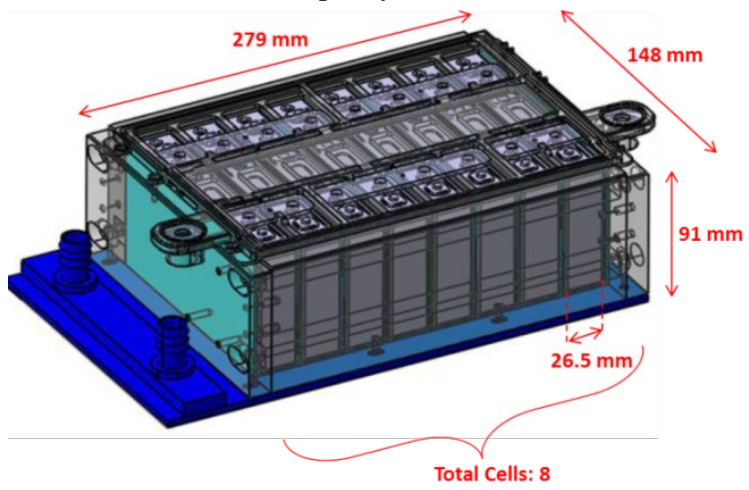

Fig. 3 Lithium ion battery module

The cells are held together in stack using arrangement of end plates with four threaded rods that provided high compressive force of $11 \mathrm{kN}$ to contain thermal expansion of cells during operation, and to provide proper thermal contact for the flow of heat from cell interiors to side/bottom via metal spacer plates. Heat load per cell could vary from 5 to $50 \mathrm{~W}$ which accounts to total heat loss in the range of 40 to $400 \mathrm{~W}$ from given battery module.

\section{BATTERY THERMAL MODELLING}

A typical high voltage battery thermal management system consists of:

- Heat extraction module (to extract heat from cells)

- Heat transfer module (to transfer heat from module to remote location)

- Heat dissipation module (to dissipate heat from transfer module to ambient air - ultimate heat sink)

Fig. 4 presents basic elements of battery thermal management system (BTMS) which includes (in direction of heat flow): 1) battery cells as heat source separated from each other by electrical insulating interface plates, 2) electrically insulating thermal interface material below cell base, 3 ) heat transfer device, 4) remotely located heat sink and 5) ambient air flow mechanism over heat sink. In Fig.5, thermal resistance network from battery cell to ambient air is demonstrated. Please note, current investigation is targeted at thermal solution for highend (high power) batteries for PHEV/EVs. For low end battery systems, simple forced air circulation system using ambient air can be used to remove and dissipate heat from battery cells directly. 


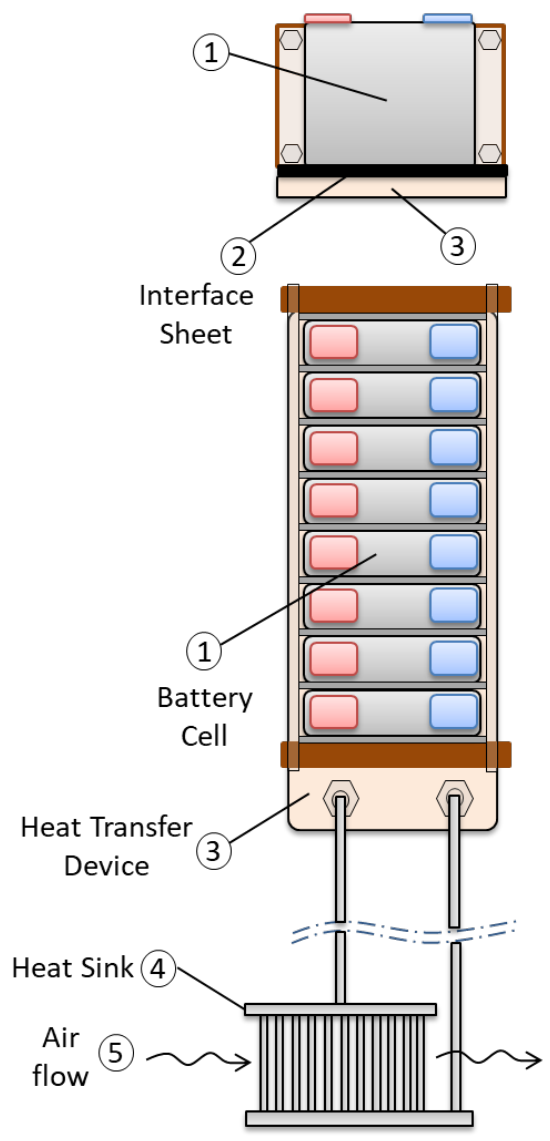

Fig. 4 Battery thermal management system schematic showing different components

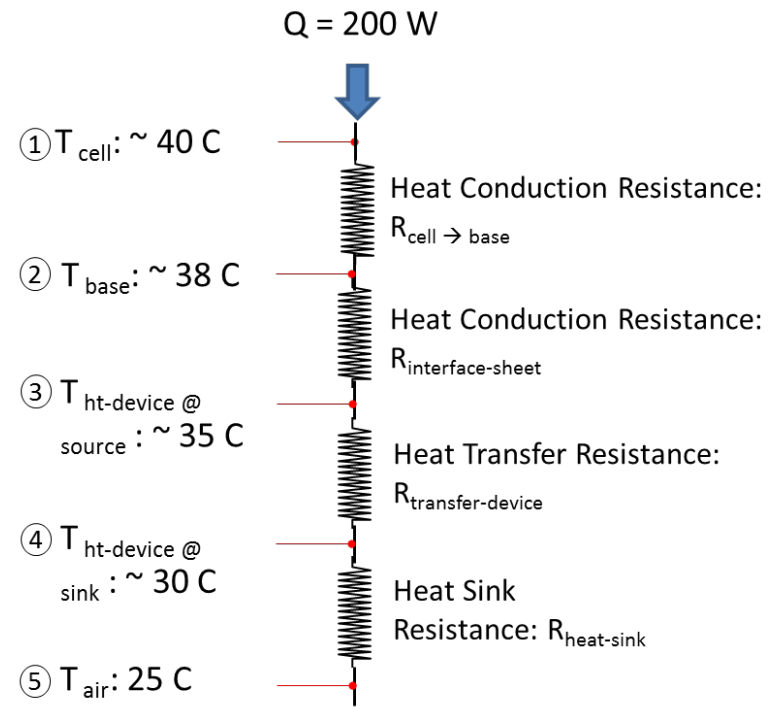

Fig. 5 Thermal resistance network for battery thermal management system with targeted temperature profile

\subsection{Thermal Resistances}

Key thermal resistance elements of thermal network, per Fig.4 \& 5, is summarized by equation (1), and discussed in detail as below.

$$
R_{t}=R_{1 \rightarrow 2}+R_{2 \rightarrow 3}+R_{3 \rightarrow 4}+R_{4 \rightarrow 5}
$$

\section{Heat Extraction Resistance $-\mathbf{R}_{1 \rightarrow 3}$}

Heat generated throughout the body of the battery cells is conducted via cell body and spacer plates to bottom side (cell base) and via electrically insulating interface sheet to heat transfer device. Total thermal resistance to heat flow can be expressed in simplified one dimensional conduction heat flow equation below:

$$
R_{1 \rightarrow 3}=\frac{t_{c}}{k_{c} A_{c}}+\frac{t_{i}}{k_{i} A_{i}}
$$

Here, Subscript c represents cell, and i represent interface layer.

$t$ is heat flow distance ( $t_{c}=$ mid to base of cell, $t_{i} \sim 1$ to $2 \mathrm{~mm}$ ), $A$ is cross section area for heat flow (cell cross sectional along horizontal) and $\mathrm{k}$ is thermal conductivity ( $\mathrm{k}_{\mathrm{i}} \sim 1$ to $3 \mathrm{~W} / \mathrm{m} . \mathrm{K}$ depending on type and material of interface layer). Thermal conductivity of cell differs in XYZ direction from 1 to $30 \mathrm{~W} / \mathrm{m}$.K depending on cell configuration, type and alignment of internal elements. Battery materials for cathode, anode and separator has relatively lower thermal conductivities $(\sim 1 \mathrm{~W} / \mathrm{m} . \mathrm{K})$ whereas materials for casting, foils/collectors have high thermal conductivity ( 200 to 400 $\mathrm{W} / \mathrm{m} . \mathrm{K}$ ) depending on material type (Zhao et al, 2018), thereby providing anisotropic thermal conductivity for overall battery cell.

\section{Heat Transfer Resistance $-\mathbf{R}_{3} \rightarrow 4$}

Heat transferred to bottom of cells need to be transported to remote location via heat transfer device, for dissipation to ambient air. Proper choice of heat transfer device for automotive battery system is very important as it dictates parasitic electric power load on batteries, overall BTMS cost and runtime reliability. In present study, specific options, design and performance of heat transfer modules for battery module, based on two-phase principle, is covered in detail. Equation (3) denotes thermal resistance for heat transfer device.

$$
R_{h t}=\sum_{j=0}^{n} \frac{1}{h_{j} A_{j}}
$$

Where, $\mathrm{j}$ denotes number of resistance elements in series for heat transfer device, $\mathrm{h}\left(\mathrm{W} / \mathrm{m}^{2} . \mathrm{K}\right)$ is heat transfer coefficient for each element and $\mathrm{A}$ is exposed area for heat transfer at each stage.

For heat pipe system, transfer resistance $\left(\mathrm{R}_{\mathrm{hp}}\right)$ can be expressed as:

$$
R_{h p}=\frac{1}{h_{e v} A_{e v}}+\frac{1}{h_{c d} A_{c d}}
$$

Where, ev denotes evaporator parameters and cd denotes condenser parameters.

Different design options for heat transfer device based on capillary heat pipes, pulsating heat pipe and loop heat pipe have been discussed and compared in the next section. It should be noted that for long heat transport distances, that are unrealistic for passive two-phase devices like heat pipes and pulsating heat pipe due to their sizing, performance and cost, secondary mechanically pumped coolant loop with cold plate and pump could be used, in conjunction with two phase devices.

\section{Heat Dissipation Resistance $-\mathbf{R}_{4} \rightarrow 5$}

From transfer device, heat has to be dissipated to ambient by forced air convection. Generally, low temperature on sink side of heat transfer device would constitute finned surfaces from where heat can be removed by air movers. In Equation (5), convection thermal resistance for air cooled heat sink is formulated. As heat transfer coefficient $\left(h_{a}\right)$ for air flow is quite low $\left(\sim 20\right.$ to $\left.35 \mathrm{~W} / \mathrm{m}^{2} . \mathrm{K}\right)$ so larger extended surfaces $\left(\mathrm{A}_{\mathrm{a}}\right)$ are required for heat dissipation to ambient air.

$$
R_{h s}=\frac{1}{h_{a} A_{a}}
$$


In Fig. 5, temperature profile that is expected in battery thermal management system is depicted for ease of understanding and discussion purpose. Here, equal share of temperature difference is allocated to each of heat removal, heat transfer and heat dissipation element of thermal resistance. Depending on battery geometrical, electrical and thermal specifications, and location of battery in the vehicles, the relative share can change. Nonetheless, available temperature difference $\sim 15 \mathrm{C}$ would be available temperature envelope, which is quite severe thermal target, thereby projecting the need for efficient thermal technologies for battery cooling.

\section{BATTERY COOLING ARCHITECTURES}

In this section, different cooling options based on two-phase technologies are proposed and discussed:

\subsection{Cell Level Cooling: Heat Removal Function}

At cell level, embedded heat pipe (EHP) plate (referred to as heat pipe cooling plate) can be used instead of metal spacer plates to transfer heat from inter-cell spaces to heat transfer device. Fig. 6 present heat pipe based heat extraction system from battery module (left) using heat pipe cooling plates (right) positioned between individual cells. Heat pipe cooling plates, which comprise of $x 4$ pcs, diameter 6 , heat pipes flattened to $1.2 \mathrm{~mm}$, showed high heat transfer capability (Fig.7) and exhibited $45^{\circ} \mathrm{C}$ evaporator steady state temperature ( $T_{\text {hp-evap }}$ ) at $50 \mathrm{~W}$ heat load per plate, while cooled by cold plate with $20 \mathrm{C}$ coolant inlet temperature $\left(\mathrm{T}_{\mathrm{cp}-}\right.$ in).
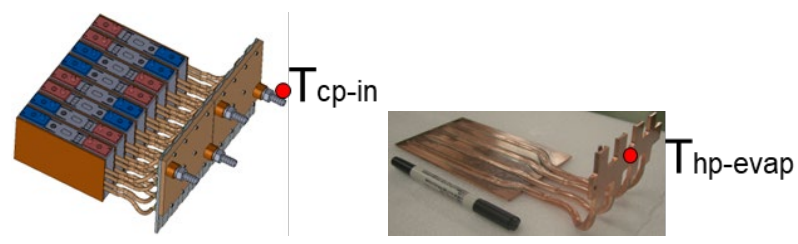

Fig. 6 Heat pipe for cell level cooling in battery module with cold plate heat transfer; system representation (left), heat pipe cooling plate sample (right)

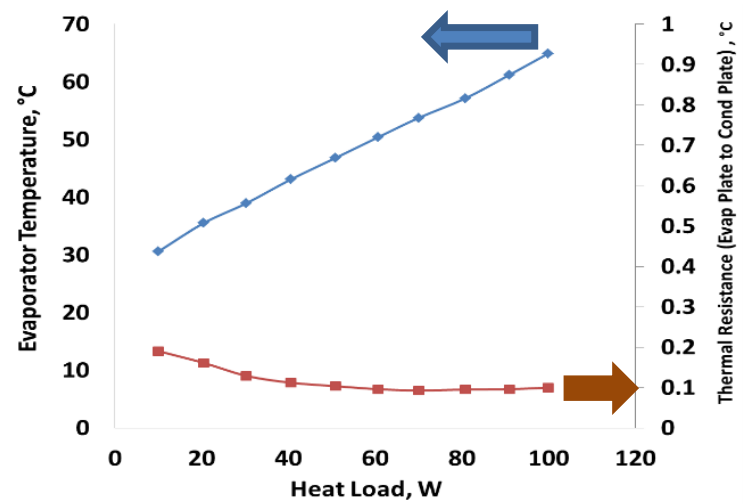

Fig. 7 Heat load dependence of heat pipe cooling plate evaporator temperature and overall thermal resistance

When compared to metal spacer plates, heat pipe cooling plates provide manifold advantages; firstly, thermal conductivity of heat pipe plates can be more than 5 times higher (depending on number of heat pipes and geometrical parameters of plate) than metal plate which would translate into lower thermal resistance between cells and heat transfer device. Secondly, heat pipe cooling plates help to transfer heat to remotely located heat transfer device like cold plate or secondary heat pipe loop (safety design against liquid leakage near high voltage battery). Thirdly, as compared to direct air-cooled battery cells, heat pipe plates provide compact battery modules (owing to thin form factor possible with heat pipes). However, due consideration need to be given to heat pipe routing and structural support to reduce system complexity. Constant thermal resistance from evaporator to cold plate (Fig. 7) was displayed by heat removal system over 10 to $100 \mathrm{~W}$, proving high heat acquisition capacity of two phase system.

\subsection{Module Level Cooling: Heat Transfer Function}

Typical heat transfer mechanism used for battery cooling is liquid cooled cold plate with active flow mechanism (mechanical pump), and dedicated or shared radiator (finned heat sink). Main issues with cold plate based system are poor temperature uniformity for module cells (due to single phase heat transfer), leakage issues in high voltage areas (safety aspects), bulky system (due to complicated flow connections, heavy cold plates and larger amount of liquid flow involved), reliability issues (prone to pump failure) and expensive system (machined cold plates, quick connectors).

Fig. 8 depicts different cooling architectures for vehicle battery module, which are systematically compared from performance, mechanical and commercial viewpoint in Table 1. X-axis shows the length scale whereas Y-axis present solution type (active/passive) on left side, and relative level of complexity for each solution, on right side. From top, option\#1 is conventional cold plate heat transfer system, which provide single loop active solution for battery cooling. Option\#2 is two loop hybrid solution with pulsating heat pipe (PHP) to transfer heat from battery module to outside of pack, from where it could be further transported using pumped cold plate system to remote location. In option\#3, PHP is replaced by embedded heat pipes (EHP) whereas in option\#4, pumped loop is replaced by loop heat pipe (LHP). In summary, from top to bottom, in Fig. 8, solution is trending from active to more passive operation and from single phase to two phase heat transfer. Mix of single and two phase (or active and passive heat transfer) is referred to as hybrid solution, which provide usefulness of both technologies. For comparison purpose, a genuine distance scale of $2.5 \mathrm{~m}$ is assumed from battery to ambient heat sink in vehicle, which could be dedicated radiator or shared radiator with other electrical and power electronic systems. It should be noted that relative size of components, in Fig. 8, represents actual sizing design intention e.g. option\#1 cold plate size corresponds to battery size, option\#2 PHP and option\#3 EHP length corresponds to battery length + heat transfer distance to cold plate location, option\#2 \& 3 , cold plate size corresponds to downsized version (2 to 3 times smaller than battery cold plate), option\#4 EHP size corresponds to battery module size.

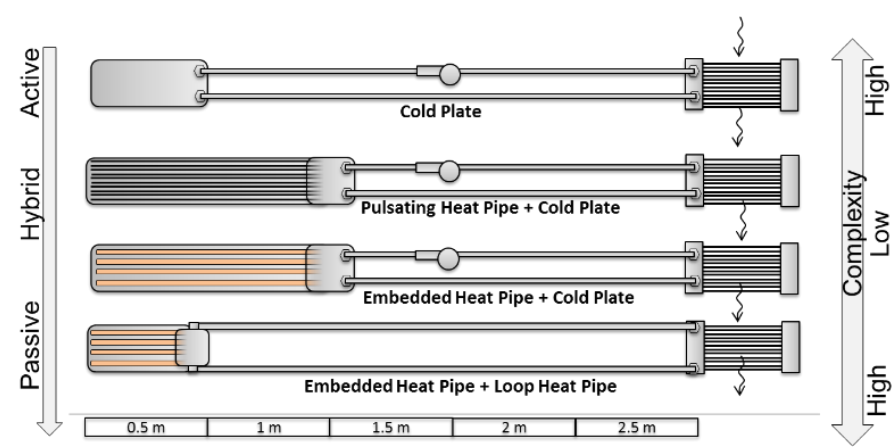

Fig. 8 Different battery cooling architecture based on two and single phase technologies

Both PHP and EHP technologies have limitation on max possible heat transfer distance, which could be in range of 0.5 to $1 \mathrm{~m}$, depending on thermal targets. For lengths longer than $1 \mathrm{~m}$, both technologies tend to be bulky, low-performance and expensive thereby restricting their length scale to less than $1 \mathrm{~m}$. For pumped cold plate and LHP, heat 
transfer distances which could be encountered in an automotive is very much possible without significant challenges, as demonstrated by different researchers (Singh et al, 2013, 2014).

Please note, Fig. 8 only demonstrate cooling architectures for one battery module for sake of simplicity in discussion. As seen from figure, complexity is high for both, pumped cold plate option due to piping and connections need to combine number of cold plates with manifold and other balance of system (pump, radiator etc.), and for loop heat pipe option due to interfacing of LHP evaporator with battery module(s). For LHP evaporator, we can have two options; flat or cylindrical evaporator. From integration viewpoint, flat evaporator is better than cylindrical evaporator as it could be adjusted in limited thickness under battery module without need for extra space, and will therefore help to downsize EHP carrier plate length. From performance and manufacturing viewpoint, cylindrical evaporator would be better than flat evaporator due to ease in fluid management and high yield rate from production processes. Nonetheless, EHP segment would be needed for both evaporator types, for flat evaporator, EHP module thermal resistance is expected to be less than cylindrical evaporator, because of requirement to place cylindrical evaporator outside battery module footprint (due to battery pack stack-up height limitations). Additionally, Interfacing of EHP module and flat evaporator would be easier than cylindrical evaporator. To conclude, choice of evaporator type and interfacing details would depends on layout of battery module in system and extent/location of volumetric space for thermal solution.

Table 1 provides comprehensive comparison of four options which concludes that each design architecture have specific niche, merits and demerits. EV battery thermal requirements are very much dependent on battery modules layout, their location in vehicle, module thermal specifications, structural constraints for cooling device integration etc. If below options are targeted on proper vehicle type and specification mix, it would provide best advantages while minimizing technology risks.

In Fig. 9, overall performance comparison based on temperature difference, $\triangle \mathrm{T}_{\mathrm{cb}-\mathrm{a}}$, from cell base (at heat transfer device side) to ambient air is provided for outlined battery architectures. This will include thermal resistance of heat transfer device, $\mathrm{R}_{3 \rightarrow 4}$, and heat dissipation device, $\mathrm{R}_{4 \rightarrow 5}$, as represented by equation (6).

$$
R_{3 \rightarrow 5}=R_{3 \rightarrow 4}+R_{4 \rightarrow 5}
$$

Further, temperature difference can be deducted from equation (7), by multiplying LHS of equation (6) with module heat load, $\mathrm{Qm}$.

$$
\Delta \mathrm{T}_{\mathrm{cb}-\mathrm{a}}=\mathrm{R}_{3 \rightarrow 5} \cdot \mathrm{Q}_{\mathrm{m}}
$$

\begin{tabular}{|c|c|c|c|c|}
\hline Parameter & Cold Plate & $\begin{array}{l}\text { Pulsating Heat Pipe + } \\
\text { Cold Plate }\end{array}$ & $\begin{array}{c}\text { Embedded Heat Pipe + } \\
\text { Cold Plate }\end{array}$ & $\begin{array}{c}\text { Embedded Heat Pipe }+ \\
\text { Loop Heat Pipe }\end{array}$ \\
\hline Operating Mode & Fully Active & Passive + Active & Passive + Active & Fully Passive \\
\hline Heat Transfer Mode & Single Phase & Single + Two Phase & Single + Two Phase & Two Phase \\
\hline Relative Weight & $\begin{array}{l}\text { High (larger coolant } \\
\text { amount and heavy } \\
\text { structures) }\end{array}$ & $\begin{array}{l}\text { Medium (smaller cold } \\
\text { plate) }\end{array}$ & $\begin{array}{l}\text { Medium to Low (smaller } \\
\text { cold plate, heat pipes are } \\
\text { lighter than PHP) }\end{array}$ & $\begin{array}{l}\text { Low (lesser fluid charge, } \\
\text { lightweight structures) }\end{array}$ \\
\hline Safety Index & $\begin{array}{l}\text { High risk (Prone to } \\
\text { leakage in high voltage } \\
\text { area) }\end{array}$ & $\begin{array}{l}\text { Low leakage issues } \\
\text { (unbound liquid charge in } \\
\text { PHP can be a concern) }\end{array}$ & $\begin{array}{l}\text { No leakage issue (HP } \\
\text { charge is bound and } \\
\text { negligible even if leak } \\
\text { happens) }\end{array}$ & $\begin{array}{l}\text { No leakage issues (LHP } \\
\text { has unbound charge but it } \\
\text { I outside battery pack } \\
\text { area) }\end{array}$ \\
\hline Price Level & High (machined parts) & $\begin{array}{l}\text { High to Medium (PHP } \\
\text { manufacturing cost still } \\
\text { high) }\end{array}$ & $\begin{array}{l}\text { Medium to low } \\
\text { (embedded heat pipe } \\
\text { technology is mature) }\end{array}$ & $\begin{array}{l}\text { High to Medium (LHP } \\
\text { technology is still under } \\
\text { developed for mass } \\
\text { production) }\end{array}$ \\
\hline $\begin{array}{l}\text { Scope for } \\
\text { Commercialization }\end{array}$ & $\begin{array}{l}\text { Already commercial } \\
\text { but limited future } \\
\text { scope (need high end } \\
\text { cold plates to improve } \\
\text { scope) }\end{array}$ & $\begin{array}{l}\text { Scope limited to specific } \\
\text { low to medium end } \\
\text { carlines }\end{array}$ & $\begin{array}{l}\text { Very high scope for both } \\
\text { low to high end carlines }\end{array}$ & $\begin{array}{l}\text { Good scope for high end } \\
\text { EVs, and battery vehicles } \\
\text { expected to operate in } \\
\text { adverse climates }\end{array}$ \\
\hline
\end{tabular}

Table 1 Comparison of different battery cooling architectures 
It should be noted that this comparison should be treated as relative assessment of heat pipe based solution as compared to baseline cold plate case (absolute values are not important as these could vary significantly depending on system design and modelling assumptions). For option\#2, significant increase from option\#1 results due to addition of extra heat transfer loop, lower heat transfer coefficient for PHP (evaporation and condensation $\sim 1500 \mathrm{~W} / \mathrm{m}^{2} . \mathrm{K}$ ) and downsizing of cold plate for pumped loop. In option\#3, there is improvement in thermal resistance due to superior evaporation and condensation process for capillary heat pipe $(\sim$ 5000 to $7500 \mathrm{Wm}^{2} . \mathrm{K}$ ). For option\#4, there is significant enhancement resulting from developed LHP evaporator (as compared to capillary heat pipe) and two phase condenser (from heat sink to ambient air). Improvements would be possible for option\#2 and \#3 by using more developed cold plates, refrigerant loop instead of pumped loop, and improvement of PHP device performance for option\#2.

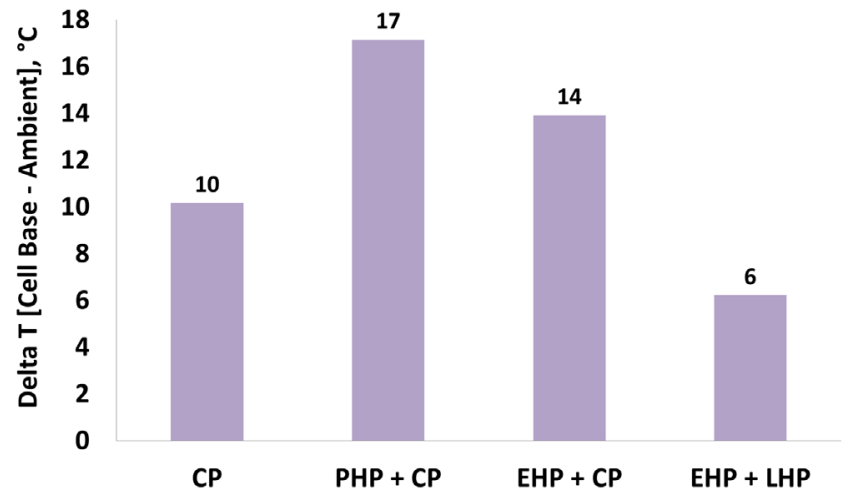

Fig. 9 Performance comparison of battery cooling architectures

Proposed architectures are further compared on the basis of battery module temperature uniformity, in Fig.10. Here, thermal uniformity, $\triangle$ $\mathrm{T}_{\mathrm{u}}$, is calculated from heat transfer device resistance, $\mathrm{R}_{3 \rightarrow 4}$, using equation (8) below:

$$
\Delta \mathrm{T}_{u}=\mathrm{R}_{3 \rightarrow 4} \cdot \mathrm{Q}_{\mathrm{m}}
$$

In the comparison, heat loss per module $\sim 200 \mathrm{~W}$ is assumed, which shows that PHP solution would be more adapted to low end modules whereas LHP solution could be use for high end modules $(>200$ $\mathrm{W} /$ module). EHP (option\#3) is more universal solution which could be used for low to high end modules owing to mature technology, high runtime reliability, relative safer and above all lightweight and reasonable price which are technology promoters in automotive sector.

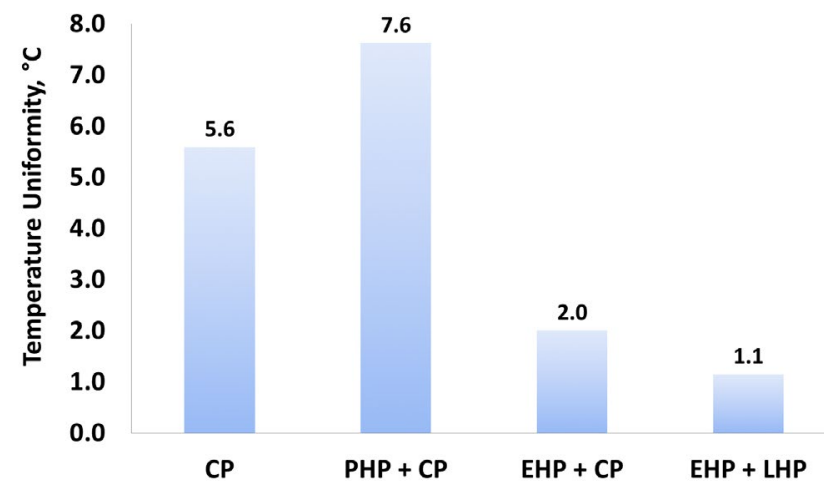

Fig. 10 Temperature uniformity possible with different battery cooling architectures

\subsection{Heat Sink Cooling: Heat Dissipation Function}

Heat sink thermal resistance is one of most significant resistance to heat flow path from cells to ambient air ( $>40$ to $70 \%$ depending on overall system resistance and configuration) which is due to poor heat transfer coefficient for air and lower heat transfer coefficient of radiator coolant. Obvious way to reduce this resistance is to add more extended surfaces on heat sink, and improve flow coefficient on coolant and air side using enhanced surfaces. One of innovative approach would be to use two phase condenser for heat dissipation to air which have potential to reduce heat sink resistance by more than $30 \%$. This could be achieved by using two-phase refrigerant compression loop instead of single phase pumped loop, or by replacing pumped cold plate loop by two-phase loop heat pipe (option\#4).

\section{TECHNOLOGIES COMPARISON}

In order to compliment discussion and conclusions provided in section 4, comparison of keys technologies has been done in this section, in accordance with their niche and advantages. For instance, embedded heat pipes and pulsating heat pipes are more compliant with collecting heat from battery module and transfer to periphery/outside of battery pack (within 0.5 to $1 \mathrm{~m}$ range), whereas loop heat pipes and pumped cold plate are competent to transport high heat load to dissipation location i.e. radiator ( $\sim 1$ to $5 \mathrm{~m}$ range) in automotive.

\subsection{Embedded Heat Pipe Vs Pulsating Heat Pipes}

Embedded heat pipe module (Fig. 11) with $\mathrm{x} 8 \mathrm{pcs}$, diameter $8 \mathrm{~mm}$ flattened, copper water heat pipe integrated into aluminum base plate, was used to transport $60 \mathrm{~W}$ heat load from battery module base to ambient air. Evaporator base dimensions were $360 \mathrm{~mm}(\mathrm{~L})$ × $220 \mathrm{~mm}(\mathrm{~W})$ × $6 \mathrm{~mm}(\mathrm{~T})$, condenser length was $127 \mathrm{~mm}$ and provided with forced air flow $\sim 1.5$ $\mathrm{m}^{3} / \mathrm{min}$. With uniformly heated evaporator section, module was able to maintain average evaporator base temperature of $33{ }^{\circ} \mathrm{C}$ and condenser base temperature of $29.7^{\circ} \mathrm{C}$, which account for module thermal resistance of $0.055^{\circ} \mathrm{C} / \mathrm{W}$.
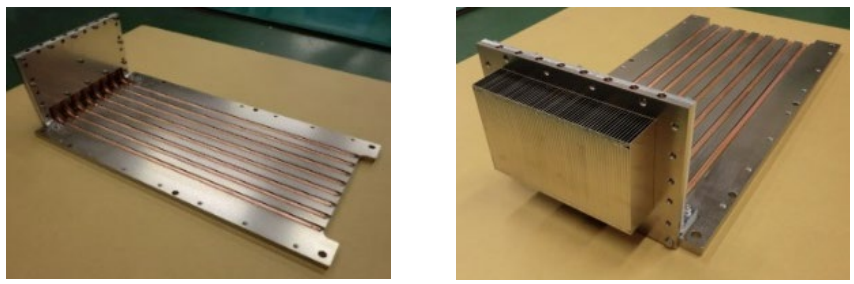

Fig. 11 Embedded Heat Pipe Module

PHP, with aluminum container and butane as working fluid, (Fig. 12) and dimensions $400 \mathrm{~mm}(\mathrm{~L}) \times 50 \mathrm{~mm}(\mathrm{~W}) \times 2 \mathrm{~mm}(\mathrm{~T})$ was characterize for this study. Tests were conducted with $350 \mathrm{~mm}$ evaporator length uniformly heated by $30 \mathrm{~W}$ applied heat load, and $50 \mathrm{~mm}$ condenser length cooled using cold plate with water flow rate of $0.5 \mathrm{lit} / \mathrm{min}$. Under steady state, PHP was able to maintain $30.4 \mathrm{C}$ evaporator surface temperature and $20.7 \mathrm{C}$ condenser surface temperature, which accounts to device thermal resistance of $0.33 \mathrm{C} / \mathrm{W}$. For similar width $(\sim 150 \mathrm{~mm}$ active dimension, ignoring attachment area) as EHP, $\mathrm{x} 3$ pcs of PHP would be needed, which would exhibit total thermal resistance of $0.11 \mathrm{C} / \mathrm{W} \sim$ almost 2 times of embedded heat pipe module. In spite of minor differences in test samples, the experimental results are able to demonstrate superior performance of EHP as compared to PHP technology, and allocate working niche to both technologies. 


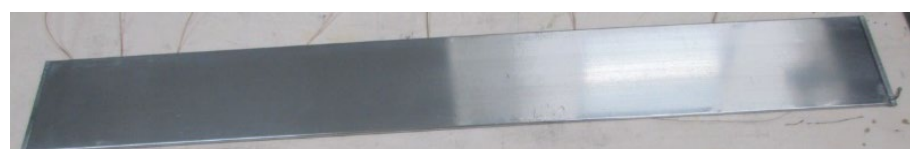

Fig. 12 Pulsating Heat Pipe

\subsection{Loop Heat Pipe Vs Pumped Cold Plate}

For comparing two phase versus single-phase heat removal process, three different cases are considered as below.

- $\quad$ Single phase pumped cold plate (Fig. 13), with dimensions $122 \mathrm{~mm}$ (L) x $86 \mathrm{~mm}(\mathrm{~W}) \times 10 \mathrm{~mm}(\mathrm{~T})\left(\sim 104.9 \mathrm{~cm}^{3}\right.$ volume), was applied with $1100 \mathrm{~W}$ heat load resulting in cold plate case temperature $24.9^{\circ} \mathrm{C}$ and coolant water mean temperature $\sim 18.2^{\circ} \mathrm{C}$. Cold plate thermal resistance was $0.006^{\circ} \mathrm{C} / \mathrm{W}$.

- $\quad$ Cylindrical LHP evaporator, $158 \mathrm{~mm}$ length, $25 \mathrm{~mm}$ diameter $(\sim 77.5$ $\mathrm{cm}^{3}$ volume), copper container, nickel wick and water as working fluid, as shown in Fig 14. When subjected to $600 \mathrm{~W}$, under steady state, evaporator body temperature of $87.5^{\circ} \mathrm{C}$ and vapour line temperature of $86.7^{\circ} \mathrm{C}$ was achieved, which corresponds to evaporator resistance of $0.0013{ }^{\circ} \mathrm{C} / \mathrm{W} \sim 4.5$ times lower than single phase cold plate.

- $\quad$ Flat LHP evaporator, $100 \mathrm{~mm}(\mathrm{~L})$ x $29 \mathrm{~mm}$ (W) x $23 \mathrm{~mm}$ (T) ( 66.7 $\mathrm{cm}^{3}$ volume), with copper container, nickel wick, water as working fluid, was subjected to $340 \mathrm{~W}$ heat load, resulting in $100{ }^{\circ} \mathrm{C}$ evaporator temperature and $99{ }^{\circ} \mathrm{C}$ vapour temperature. This accounts to $0.0029{ }^{\circ} \mathrm{C} / \mathrm{W}$ evaporator thermal resistance $\sim 2$ times lower than pumped cold plate resistance

It can be concluded, from above three test examples, that LHP evaporator with different shape (flat, cylindrical), different heat transport lengths ( $1 \mathrm{~m}$ for cylindrical, $250 \mathrm{~mm}$ for flat) and higher heat flux than single phase cold plate (per device volume) is able to demonstrate more than 2 to 4 time lower thermal resistance to heat removal process, than pumped cold plate.

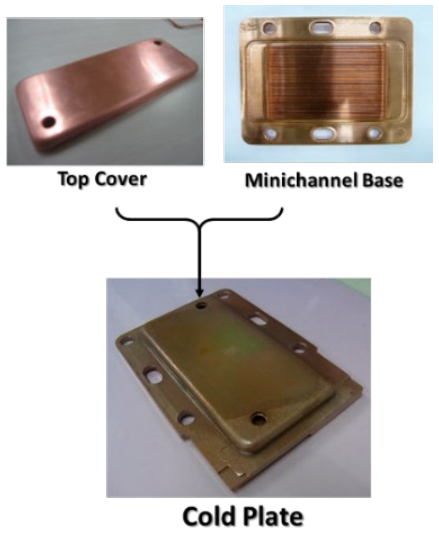

Fig. 13Microchannel Cold Plate

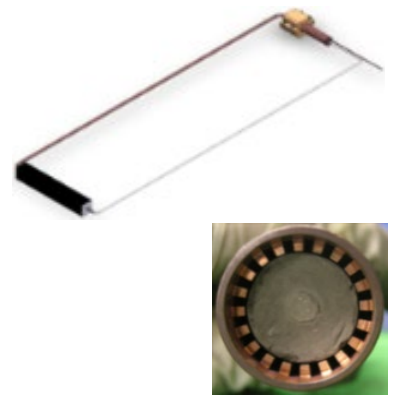

Fig. 14 Cylindrical Loop Heat Pipe Evaporator

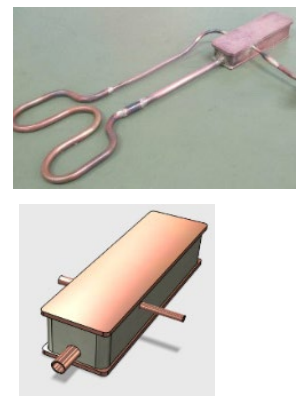

Fig. 15 Flat Loop Heat Pipe Evaporator
Overall, two phase based cooling system for electric vehicle battery will help to improve system cooling performance, reliability, safety against liquid leakage hazard and overall system weight, which is critical for automotive applications.

\section{CONCLUSIONS}

The paper can be summarized as below:

- Battery cooling solution should critically consider heat removal from cells, transfer heat to remote location and dissipate to ambient air

- Different cooling architectures for lithium-ion battery module with $350 \times 150 \times 100 \mathrm{~mm}^{3}$ size, 8 to 12 pes prismatic cells, and 40 to 400 $\mathrm{W}$ heat load is proposed, evaluated and compared

- Heat pipe can enhance local heat removal from cells by 2 to 3 times more than what is possible with metal spacers, however integration complexity need to be addressed

- Cooling architectures, for heat transfer from battery module, ranges from traditional single phase pumped cold plate, hybrid solution with pulsating heat pipe and cold plate loop or embedded heat pipes and cold plate loop, and total passive solution based on embedded heat pipes and loop heat pipe, has been proposed and examined.

- Passive heat transfer architectures will provide high performance, runtime reliability, safer working conditions, better temperature uniformity, lightweight and cheaper solution, as compared to single phase pumped cold plate solution.

- Introducing pulsating heat pipe or embedded heat pipes into cold plate cooled design will improve cooling system safety against leak however system thermal resistance will likely to increase, which will need additional design measures to restore system performance.

- $\quad$ Embedded heat pipe + loop heat pipe based fully passive solution will have best temperature uniformity $\left(\sim<2^{\circ} \mathrm{C}\right)$ and lowest thermal resistance (battery cell to ambient) than other proposals.

- $\quad$ Embedded heat pipe + cold plate pumped loop solution is most adaptable for low to high end electric vehicle from cost, technology, performance and price viewpoint.

- Embedded heat pipe based heat transfer solution can provide 2 times lower thermal resistance than pulsating heat pipe solution

- Loop heat pipe heat removal thermal resistance is 2 to 4 times lower than single phase cold plate.

\section{NOMENCLATURE}

A area $\left(\mathrm{m}^{2}\right)$

$h \quad$ heat transfer coefficient $\left(\mathrm{W} / \mathrm{m}^{2} . \mathrm{K}\right)$

$k$ thermal conductivity $(\mathrm{W} / \mathrm{m} . \mathrm{K})$

$Q \quad$ heat load $(W)$

$R \quad$ thermal resistance $\left({ }^{\circ} \mathrm{C} / \mathrm{W}\right)$

$t \quad$ thickness (m)

Subscripts

$\begin{array}{ll}a & \text { ambient/air } \\ c & \text { cell } \\ c b & \text { cell base } \\ c d & \text { condenser } \\ e v & \text { evaporator } \\ h p & \text { heat pipe } \\ h s & \text { heat sink } \\ h t & \text { heat transfer } \\ i & \text { interface } \\ j & \text { resistance element per Eq.(3) } \\ m & \text { module } \\ t & \text { total } \\ u & \text { uniformity } \\ 1,2 \ldots 5 & \text { Per Fig. } 4\end{array}$




\section{REFERENCES}

Tilley, D.S., 2018, "Thermal Management of Hybrid and Electric Vehicles: Market Size and Characteristics, Supplier Challenges and Opportunities," Proceedings of $7^{\text {th }}$ International Conference on Thermal Management for EV/HEV, 13 - 15 Feb, 2018, Berlin, Germany

Jeckel, A., 2018, "Battery Thermal Management: Key to Performance, Durability and Safety," Proceedings of $7^{\text {th }}$ International Conference on Thermal Management for EV/HEV, 13 - 15 Feb, 2018, Berlin, Germany

Ferraris, W., Casella, M., Merlo, A.M., Rinaldi, A., Rostagno, M.M., Seccardini, R., Caldevilla, A., Savi, A., Sciarretta, A., 2018, "Increasing the Electric Drive Range of EVs and PHEVs through New Concepts of Thermal Conditioning for ePT Systems and Cabin," 7th International Conference on Thermal Management for EV/HEV, 13 - 15 Feb, 2018, Berlin, Germany

Singh, R., Mochizuki, M., Saito, Y., Yamada, T., Nguyen, T., Nguyen, Ti., 2015, "Heat Pipes Applications in Cooling Automotive Electronics," Heat Pipe Science and Technology: An International Journal 6 (3), 1-13 http://dx.doi.org/10.1615/HeatPipeScieTech.2016017225

Singh, R., Mochizuki, M., Saito, Y., Yamada, T., Nguyen, Ti., Nguyen, T., 2016, "Cooling of LED Headlamp in Automotive by Heat Pipes", Proceedings of Joint $18^{\text {th }}$ International Heat Pipe Conference and the $12^{\text {th }}$ International Heat Pipe Symposium, June 12-16, 2016, Jeju, Korea
Orr, B., Akbarzadeh, A., Mochizuki, M., Singh, R., 2016, “A review of car waste heat recovery systems utilising thermoelectric generators and heat pipes," Applied Thermal Engineering, 101, 490 - 495 http://dx.doi.org/10.1016/j.applthermaleng.2015.10.081

Mochizuki, M., Saito, Y., Mashiko, K., Nguyen, T., Singh, R., 2016, "High Power Heat Removal by Heat Pipes \& Two Phase Heat Transfer for Electric Vehicle," Proceedings of Joint $18^{\text {th }}$ International Heat Pipe Conference and the $12^{\text {th }}$ International Heat Pipe Symposium, June 12-16, 2016, Jeju, Korea,

Zhao, Y., Hunt, I., Dondelewski, O., Krishnakumar, G., Campbell, I., Zhang, T., Patel, Y., Marinescu, M., Offer, G., 2018, "Understanding the impact of thermal management strategies on battery," Proceedings of $7^{\text {th }}$ International Conference on Thermal Management for EV/HEV, 13 - 15 Feb, 2018, Berlin, Germany

Singh, R., Mochizuki, M., Saito, Y., Yamada, T., Nguyen, T., Nguyen, Ti., Akbarzadeh, A., 2013, "Loop Heat Pipe Applications in Automotive Thermal Control," Proceedings of the $17^{\text {th }}$ International Heat Pipe Conference, October 13-17, 2013, Kanpur, India

Singh, R., Nguyen, T., Mochizuki, M., 2014, Capillary evaporator development and qualification for loop heat pipes, Applied Thermal Engineering 63, 406-418

http://dx.doi.org/10.1016/j.applthermaleng.2013.10.059 